\title{
Business University Student Entrepreneurial Competencies: Towards Readiness for Globalization
}

\author{
Nerisa Paladan D.B.A. \\ Faculty of School of Business and Social Sciences, International University of Grand-Bassam, Ivory Coast
}

Copyright $(\mathcal{C} 2015$ by authors, all rights reserved. Authors agree that this article remains permanently open access under the terms of the Creative Commons Attribution License 4.0 International License

\begin{abstract}
Business School around the world is challenge to promote entrepreneurship education that would develop the personal entrepreneurial competency of their business students. With the growing importance of globalization business students must be competitive by enhancing their personal entrepreneurial competencies. This research aimed to assess the level of personal entrepreneurial competencies of business students in an international university in West Africa; to determine which personal entrepreneurial competencies they excel and which needs improvement; and to recommend how to enhance their level of personal entrepreneurial competencies for them to be globally competitive. A descriptive type of research was adopted; seventy seven (77) business students in the upper level from sophomore to senior are the respondents of this study; they were surveyed and their level of personal entrepreneurial competencies were measured using Personal Entrepreneurial Competencies (PEC) Questionnaire with fifty five (55) questions through likert scale. Findings of the study revealed that business students have an overall fair level of personal entrepreneurial competency which is a good start towards readiness for globalization. They have moderate personal entrepreneurial competency in terms of risk taking, demand for quality and efficiency, and persistence. They need to enhance their commitment to work contract, goal setting and information seeking where business students obtained low scores. It is recommended to have a comprehensive review of their curriculum that will encourage entrepreneurship and uphold more action learning, internship, fieldwork, and establishing of mini-enterprise by students. Furthermore, they could benchmark to best practices of entrepreneurial activities of other universities across the globe.
\end{abstract}

Keywords Entrepreneurial Competency, Entrepreneurship Education, Business University Students, Globalization

\section{Introduction}

Nowadays, entrepreneurship is the main instrument motivating various nations' economic development, advancement and competitiveness [1,2]. Likewise entrepreneurship is considered as one of the best economic growth strategies to increase country's economic progress and maintain the country's competitiveness in the face of growing inclination of globalization [3]. Research studies suggest that better entrepreneurial environment leads to sustainable economic growth and the essential to move from managed economy to entrepreneurial economy [4]. Moreover, most studies have revealed that there is a positive relationship between entrepreneurship and economic development in terms of job opportunities, company's continued existence and technological change $[5,6]$.

Entrepreneurship is gradually becoming an essential requirement for success in a progressively globalized and aggressive economy and desires to be rooted into the basic structure of society, as well as the institutions of higher education. Thus, universities have a practical task in promoting entrepreneurship education to build up regional and society economies [7]. For this reason it is vital to provide a positive image of entrepreneurship as career option to encourage business students in the university by giving them resources and other facilities that will boost their entrepreneurial competencies. Reference [8] empathize the necessity to keep in mind that although individuals might have the appropriate entrepreneurial knowledge and skills, they still need to acquire a positive perspective about entrepreneurship for them to have courage to start a business venture.

Knowing the competencies the students need to obtain has immense significance in the field of education, because there is a potential to encourage students to become entrepreneurs. Study reveals that acquiring entrepreneurial competencies can provide students a confidence in developing businesses idea and eventually establishing new business. Thus, the objective of this study is to assess the level of personal entrepreneurial competencies of business students in an international university in West Africa. Since the university has recently offer business degree program so it would be a challenge and at the same time an opportunity to provide 
better degree program that enables students to develop their entrepreneurial competencies. Furthermore, this study determined which personal entrepreneurial competencies the business students excel and which needs improvement. Reference [9] point out that attitude plays a fundamental role in the life of a successful entrepreneur and this would help them to overcome hindrance, solve problems and accomplished task once they create their business venture. Finally, the study come-up with some recommendations on how to enhance the level of personal entrepreneurial competencies of the business students for them to be globally competitive and to persuade them to engage in entrepreneurship activities. Since entrepreneurship is a significant component of the solution to Africa's development issues [10]. This study may add to the body of knowledge in the discipline of entrepreneurship and inspired business students to further develop their personal entrepreneurial competencies. Moreover, the limitation of the study it only covers a descriptive analysis where it illustrate one of the situations in west Africa and this can also contribute to further research and comparisons.

\section{Literature Review}

Reference [11] defined entrepreneurial competencies as clusters of associated knowledge, attitudes, and skills which an entrepreneur must obtain through managerial training and development that will enable him to produce outstanding performance and maximize profit while managing a business venture or an enterprise. They pointed out that entrepreneurial competencies consist of time management, marketing management, business ethics, leadership, decision-making, and financial management. Whereas [12] emphasized the two specific types of competencies that the leaders of entrepreneurial endeavor must have, these are the personal competencies and functional competencies. In functional competencies it permits leaders to mobilize a group of people, share the entrepreneurial vision to their people; they are committed to improve their self-efficacy and to achieve their entrepreneurial vision. On the other hand pro-activeness, innovativeness, and risk taking are among the personal competencies. Likewise, [13] classify four clusters of entrepreneurial competencies that include personal and relationship, business management, entrepreneurial and human resources competencies. While [14] categorize entrepreneurial competencies into eight clusters which are team leadership, communication, trustworthiness, organizational skills, basic business skills, problem solving skills, personal traits and creativity.

One of the significance of assessing entrepreneurial competencies is to know their linked with the business performance and its growth, and thus with economic development. In the framework of entrepreneurship, competencies are specifically related to the creation, survival and/ or growth of a business [15]. Researches shows that entrepreneurial competencies are necessary for the development and survival of an organization $[14,16]$. Reference [17] in their evaluation of the impact of entrepreneurial characteristics on the performance of small scale manufacturing industries in Nigeria established that majority of the Personal Entrepreneurial Competency (PEC) of the respondents made negative contribution on the sales revenue, only demand for efficiency and product quality, information seeking; and systematic planning and monitoring had positive impact. Their study concluded that the negative attributes exhibited by the respondents in most of the PECs were critical factors in the dismal performance of the small-scale manufacturing industries, which need to be developed in the entrepreneurs through training.

Reference [18] stated that Business University plays a practical role in promoting entrepreneurship education to build up regional and society economies. Reference [19] indicated that Universities are the seedbeds of entrepreneurship to teach their students the way to think and behave entrepreneurially. Reference [20] highlighted the necessity to assume more realistic approaches to entrepreneurial training. In their study, they presented information on the current studies in entrepreneurship, emphasizing the core function of opportunity - discovering, evaluating and exploiting it and the significance of teaching techniques. They recognized action-learning approach as appropriate for entrepreneurial education, since it promotes students to expand their perspective, and develop the skills and behavior required to make them enterprising. There is a dual implication of this increasing need for entrepreneurs and the demand it calls on formal education such as teaching techniques must be rationalized to include process-oriented approaches and there is a need for lingering definition of the learning arena itself, and of the role of educational institutions particularly at the tertiary level [21].

Reference [22] suggested that the competency levels of students especially along the areas of opportunity seeking, risk taking, and self-confidence can be done by universities by reviewing the design of their curriculum to promote entrepreneurship through apprenticeship program, ocular visits, forums or symposia, linkages with SLU-EISSIF, DTI, TESDA newsletters or magazines, competitions trade fairs and exhibits competitions. Researches showed that students who partake in enterprise activities have better overall entrepreneurial characteristics, more personal control, better self-esteem and more innovation than an equal group [23, 24]. The distinctiveness that is commonly related with entrepreneurs among intermediary level students is affected by the entrepreneurial education and their enterprise experience.

The Global Education Initiative of the [25] consider that 'educating' and 'learning' needs to take place at the same time, from the early age through a lifelong learning process: It is clear that education has an critical role in shaping attitudes, skills and culture from the primary level. Entrepreneurship education offers a mix of experiential learning, skill building and most significantly mindset shift. Indeed, the earlier and more extensive the exposure to 
entrepreneurship and innovation the more likely students will turn into entrepreneurial in one form or another at some stage in their lives. Addressing entrepreneurship education necessitates working with current education systems to integrate the essential changes as well as introducing new initiatives outside of existing structures. It examined further that entrepreneurship education requires being central to the way formal education operates. Educational institutions, at all levels (primary, secondary and higher education) must adopt the 21 st century methods and tools to build up the appropriate learning environment for encouraging creativity, innovation, and the ability to "think out of the box" to solve problems. This entail a fundamental rethinking of educational systems, that includes training of teachers, how students are assess, the reward system, and incentives for performing students, teachers, and institutions. There is also a need for new multi-disciplinary approaches and interactive teaching methods.

That globalization has led to a shift in developed countries from an industrial to an entrepreneurial model of production [26]. Considering the effect of globalization on entrepreneurship can help the Business Universities to act upon, to develop business students who will be the future entrepreneurs and investors to gain insight about the opportunities and risks in the context of globalization.

\section{Methodology}

\subsection{Research Design}

The study adopted descriptive type of research in which quantitative analysis was employed using Personal Entrepreneurial Competencies (PEC) a self-rating questionnaire as the survey instrument to collect data regarding the level of personal entrepreneurial competency of the business students and to determine which entrepreneurial competencies they excel and which needs improvement. Personal Entrepreneurial Competencies (PEC) was adapted from Management Systems International (MSI) and McBer Team as cited by [27]. The self-scoring personal entrepreneurial competency (PEC) questionnaire uses 55 items to measure ten personal entrepreneurial competencies. These items are rated using a 5-point likert scale with anchors labeled as 1- never, 2- rarely, 3sometimes, 4- usually, and 5- always. The data collection that was used for the survey was through personal meeting with the respondent. The survey instrument has a sequential number to track responses of the participant. Observation and informal conversation to the respondents was likewise utilized for validating the result of the study.

The respondents of this study were the upper level of business students from sophomore to senior, a total of 77 respondents using total enumeration. The respondents were identified and recommended by the office of the student affairs, this office is responsible in monitoring the performance and activities of the students.

The aimed of this study is to assess the level of personal entrepreneurial competency of business students in an international university in West Africa from the student's perspective and to better understand it, rather than testing any model or hypothesis. Therefore, qualitative approach is likewise undertaken [28]. This study also includes synthesizing the information obtained from various sources like informal interviews and documents into a logical description of what was discovered; which are part of a qualitative research.

\subsection{Data Analysis}

Descriptive statistics which include frequency count and percentage were used to determine the profile of the respondents in terms of gender, age, year level, nationality, parent's background and business exposure/experience. Likewise weighted mean and cross-tabular analysis was used to measure the level of personal entrepreneurial competency of the respondents which includes opportunity seeking, persistence, commitment to work contract, demand for quality \& efficiency, risk taking, goal setting, information seeking, systematic planning \& monitoring, persuasion \& networking, and self-confidence.

\section{Results and Discussion}

The research results and discussion focused on the assessment of the level of personal entrepreneurial competencies of the Business University Students in an international university in West Africa and which from the personal entrepreneurial competencies they excel and which needs improvement. It also includes the profile of the respondents.

Table 1. Personal Demographics of the Respondents

\begin{tabular}{|c|c|c|}
\hline Personal Demographic & Frequency & Percentage \\
\hline Gender & 34 & 45 \\
\hline Female & 42 & 55 \\
\hline Male & 47 & 62 \\
\hline$\underline{\text { Age }}$ & 21 & 28 \\
\hline $18-20$ & 5 & 8 \\
\hline $21-23$ & 2 & 3 \\
\hline $24-$ up & \multicolumn{2}{|l|}{} \\
\hline Not specify & 65 & 85 \\
\hline Year level & 8 & 11 \\
\hline Sophomore & 3 & 4 \\
\hline Junior & \multicolumn{2}{|l|}{} \\
\hline Senior & 68 & 89 \\
\hline Nationality & 2 & 3 \\
\hline Ivorian & 2 & 3 \\
\hline Congolese & 1 & 1 \\
\hline Nigerian & 1 & 1 \\
\hline Cameroon & 2 & 3 \\
\hline Togolese & & \\
\hline Others \& Not specify & & \\
\hline 1 reflects & 1 & \\
\hline
\end{tabular}

Table 1 reflects the personal demographic of the respondents that includes the gender, age, year level and 
nationality. First in terms of gender majority of the respondents are male which is 55 percent, but female respondents are not out number. In West Africa they are now promoting equal opportunity for women to have tertiary education. Second, majority of the respondents are under ages from 18 to 20 years old. Normally students from West Africa start their tertiary education as early as 16 years old but since the university is adopting English as medium of instruction so students need to take English preparatory course for one year before proceeding to the university degree program. Third in terms of year level, majority of the respondents are in the sophomore, since the university has recently offer a degree program so there are few junior and senior in the upper level. Before the university only offer a two-years preparatory degree for students who are going to continue their study in abroad particularly in United States of America where they have partner university. Lastly, majority of the respondents are Ivorian since the university is located at Ivory Coast. Although the university is an International school that offers global education in West Africa.

Table 2. Parents Background and Business Exposure of the Respondent

\begin{tabular}{|c|c|c|}
\hline Parents Background & Frequency & Percentage \\
\hline $\begin{array}{c}\text { Both Parents were self-employed most } \\
\text { of their working lives }\end{array}$ & 27 & 36 \\
\hline $\begin{array}{c}\text { Both Parents were self-employed for } \\
\text { some part of their working lives }\end{array}$ & 11 & 14.5 \\
\hline $\begin{array}{c}\text { One Parent were self-employed } \\
\text { foremost of her/his working lives }\end{array}$ & 11 & 14.5 \\
\hline $\begin{array}{c}\text { One Parents was self-employed some } \\
\text { part in his/her working life }\end{array}$ & 14 & 18 \\
\hline Neither parent was self-employed & 13 & 17 \\
\hline Business Exposure/Experience & 30 & 39 \\
\hline Have been involved in family business & 40 & 53 \\
\hline $\begin{array}{c}\text { Have been engaged in buying and } \\
\text { selling }\end{array}$ & 6 & 8 \\
\hline Others &
\end{tabular}

Table 2, shows the parents' background and business exposure/experience of the respondents. Majority of the parents of the respondents both were self-employed most of their working lives which is 36 percent, only 17 percent of the parents of the respondents neither were self-employed. And that is the reason why most of the respondents have business exposure either they were involved in family business or engaged in buying and selling. In others, some of the respondents have no business exposure because both of their parents are employed.

Table 3 below presents the level of personal entrepreneurial competency of the business students. Business students have 9.25 as their weighted mean which indicate a fair level of personal entrepreneurial competency. This is a good start for the students who want to choose entrepreneurship as their career option. They could still enhance their personal entrepreneurial competency as they continue to acquire more business courses and exposure to business enterprise activities provided by the university. Entrepreneurship is one of the career options for most of the graduates of these generations [29,30]. Reference [31] emphasize the necessity to offer the kind of education that is needed to develop an opportunity-oriented entrepreneurial mind set among tertiary students. Likewise, employers are looking for graduates who have an entrepreneurial mindset.

Table 3. Level of Personal Entrepreneurial Competency

\begin{tabular}{|c|c|c|}
\hline Personal Entrepreneurial Competency & $\begin{array}{c}\text { Weighted } \\
\text { Mean }\end{array}$ & Rank \\
\hline Opportunity Seeking & 9.05 & 5 \\
\hline Persistence & 9.90 & 3 \\
\hline Commitment to Work Contract & 8.71 & 8 \\
\hline Demand for Quality \& Efficiency & 10.66 & 2 \\
\hline Risk Taking & 11.03 & 1 \\
\hline Goal Setting & 8.40 & 9 \\
\hline Information Seeking & 7.96 & 10 \\
\hline Systematic Planning \& Monitoring & 9.00 & 6 \\
\hline Persuasion and Networking & 9.06 & 4 \\
\hline Self- confidence & 8.74 & 7 \\
\hline \multicolumn{2}{|c|}{ Overall PECs Rating 9.25 } \\
\hline Legend: 0-4 Weak, 5-9 Fair, 10-14 Moderate, \\
15-19 Strong, 20-25 Very Strong. \\
\hline \multicolumn{2}{|c}{ obtained the highest score in } \\
\hline
\end{tabular}

Risk taking obtained the highest score in personal entrepreneurial competency of the business students with weighted mean of 11.03; this implies that they have the entrepreneurs' ability to take risk in starting a business venture followed by Demand for Quality \& Efficiency and Persistence with computed weighted scores of 10.66 and 9.90, respectively. This signifies that they have the entrepreneurs' ability to attempt to do things better, faster, or cheaper. That they could set high standards of excellence and will not comprise on the standard they established. They are also persistent regardless of countless hindrances and failed attempts to be successful; they still try to confront themselves to pursue their business ventures.

Reference [32], specify that risk-taking involve that the entrepreneurs perceive himself as a businessman, not a gambler. He takes moderate risks if he knows he has good prospect of success. He looks for alternative solutions to problems and unconventional means based on risks versus rewards.

Reference [33], point out that demand for efficiency and quality means that the entrepreneur knows that meeting deadlines is very important and greater achievements do not come quickly and easily. So entrepreneur needs to focus on the project until it is successfully done.

However, they obtained least scores in Commitment to Work Contract, Goal Setting and Information Seeking as indicated by the weighted scores of 8.71, 8.40 and 7.96, respectively. These are considered as their weaknesses. This imply that they have low loyalty to work contract and not conscious on the work deadline. They have to develop the sense of taking full responsibility in accepting a job and must learn to acknowledge that success does not come effortlessly. They also need to learn how to set realistic and attainable 
objectives. Furthermore, they have to frequently update themselves with significant information from various sources. They need to develop their awareness of past, existing and future issues concerning their future business enterprise.

Information seeking skills means that entrepreneurs look for direct feedback on their performance and yearning timely and correct data on the answer they get. Reference [32] emphasizes that entrepreneurs desire punctual and precise data on the results they are receiving.

The following figures are the cross-tabulation of personal entrepreneurial competencies to gender, age range and year level.
Figure 1, shows that male respondents are more opportunity seeker, persistent, committed to work contract, risk taker, systematic in planning \& monitoring, and persuasive \& networking. While female respondents are better in terms of goal setting, information seeker and has more self-confidence.

Both male and female respondents have a moderate level of risk taking, demand for quality \& efficiency, and persistence and they have fair level on the other areas. Overall both male and female respondents have a fair level of personal entrepreneurial competency as indicated by the weighted scores of 9.82 and 9.64 respectively.

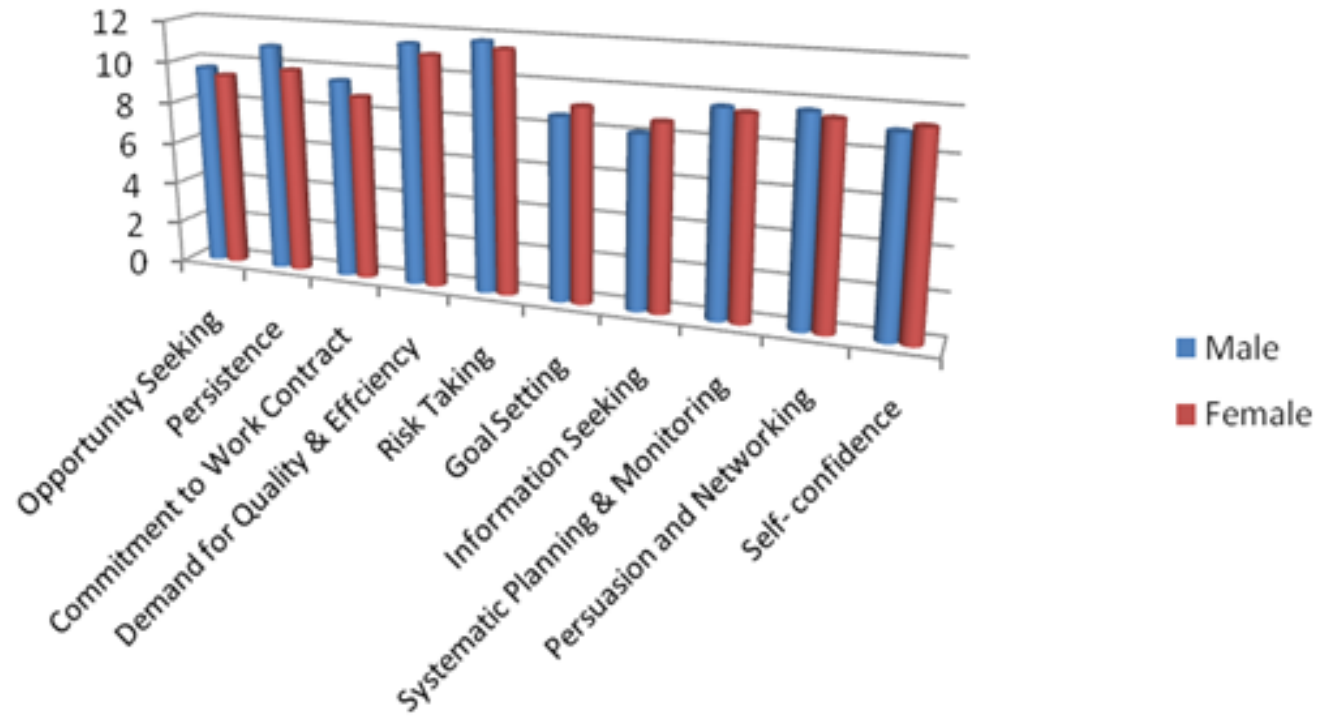

Figure 1. Personal Entrepreneurial Competency in terms of Gender

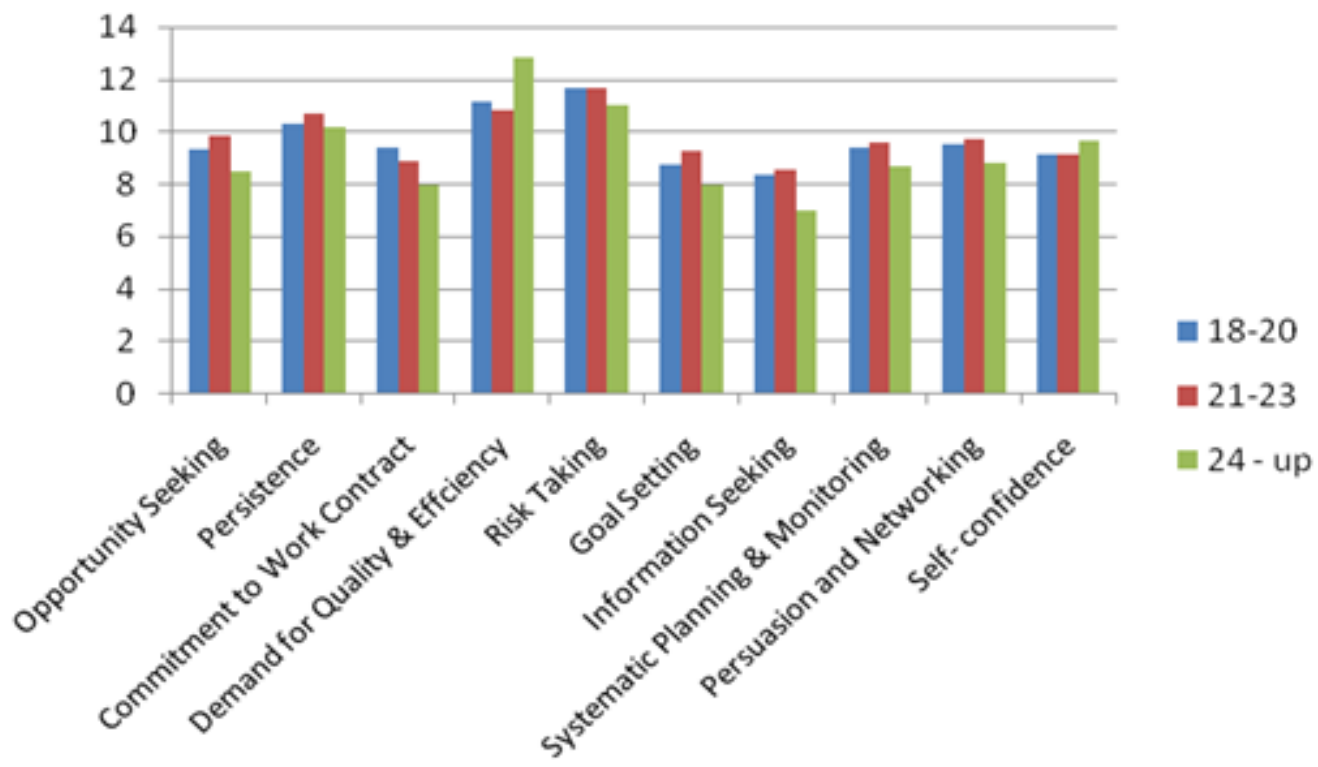

Figure 2. Entrepreneurial Competency in terms of Age Range 


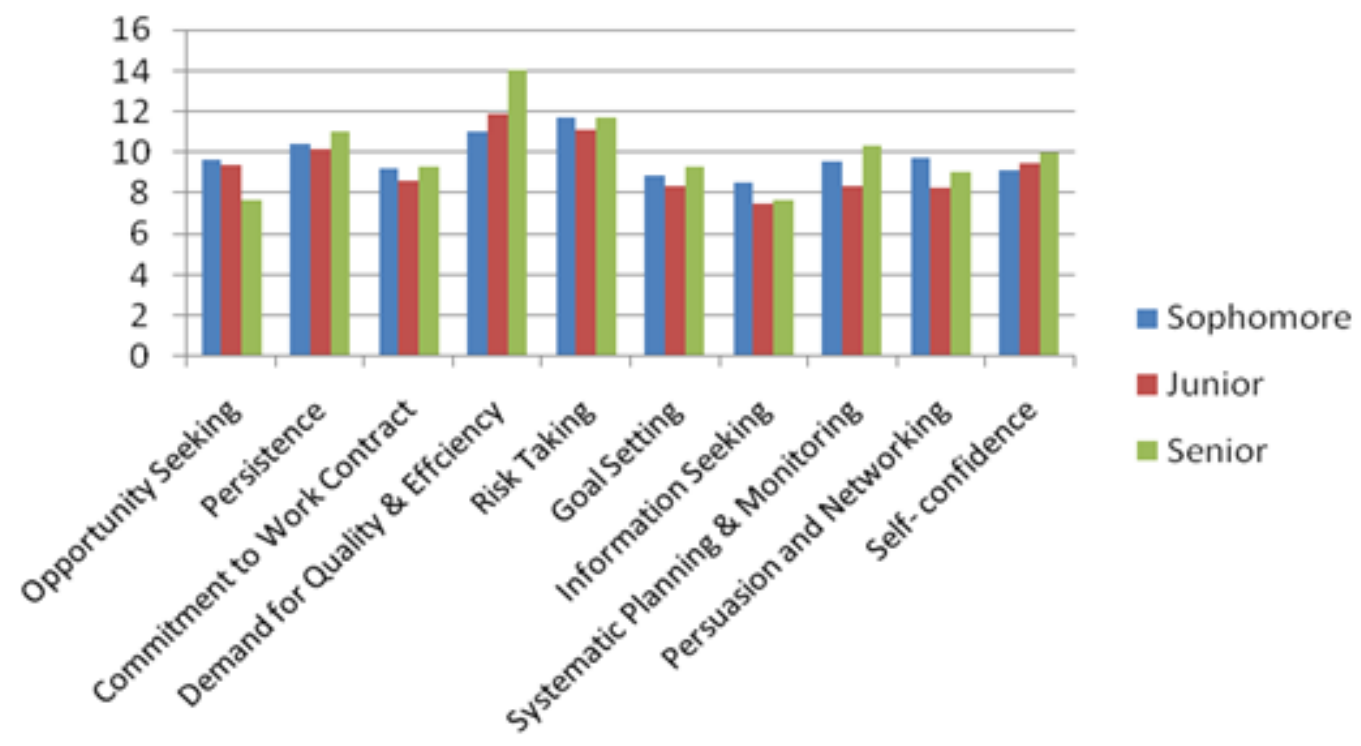

Figure 3. Entrepreneurial Competency in terms of Year Level

Figure 2 indicate that respondent's ages 21 to 23 years old are good at opportunity seeking, persistence, goal setting, information seeking, systematic planning \& monitoring, and persuasion \& networking. While respondents ages 24 and above has more self-confidence and demand for quality \&efficiency. Respondents ages 18 to 20 are better in terms of commitment to work contract. It also reflects that those respondents ages 18 to 20 and 21 to 23 have the same level of self-confidence, and risk taking.

All of the respondents have a moderate level of risk taking, demand for quality \& efficiency, and persistence. Overall regardless of age range they all have a fair level of personal entrepreneurial competency.

Figure 3 specify that the senior students are more persistent, committed to work contract, demand quality \& efficiency, goal setting, systematic planning \& monitoring and have self-confidence while sophomore are persuasive $\&$ networking, and opportunity seeker.

All of the respondents have a moderate entrepreneurial competency in terms of risk taking, demand for quality \& efficiency, and persistence where they got a high score. Overall the senior students have a moderate level of personal entrepreneurial competency while the junior and sophomore have fair level; this was reflected in their weighted score of $10.00,9.31$ and 9.78 respectively.

\section{Conclusions and Recommendations}

The business university student has a fair level of personal entrepreneurial competency. There is an opportunity for the business students to enhance further their personal entrepreneurial competencies by utilizing and taking seriously their business experience/exposure from their family business or personal business endeavor, the business courses and the entrepreneurial education that they will acquire from the university. Assessing their level of personal entrepreneurial competency provides them awareness on the need to enhance further their competencies for them to be globally competitive and facilitate their readiness towards globalization.

Risk taking, Demand for Quality \& Efficiency and Persistence are the personal entrepreneurial competencies where the business students obtained high scores and these also indicate their strength. Reference [12] point out that innovativeness, risk-taking, and pro-activeness are vital to business/enterprise survival and success. Regardless of gender and ages they have the same level of personal entrepreneurial competency. The senior students have moderate personal entrepreneurial competency as they already gain more knowledge and experience about establishing a business venture. Furthermore, business students must develop their personal entrepreneurial competencies in line with commitment to work contract, goal setting, information seeking, opportunity seeking, systematic planning and monitoring, persuasion and networking, and self-confidence for them to become successful entrepreneurs and managers.

To improve the personal entrepreneurial competency levels of the business students, it is recommended to the university to review the curriculum for business degree program that will encourage entrepreneurship and uphold more action learning, internship, fieldwork, and establishing mini-enterprise manage by the students. Also, the university could encourage students to work out activities that designed to simulate actual world situations and motivate students to organize ocular visits to small medium enterprises, forums or symposia, trade fairs and exhibits that will develop their initiative. In addition, the university could also provide mentoring programs to coach students and request selected successful practicing entrepreneurs to share how they started their business venture and inspire students how to succeed. Moreover, the university could benchmark to best practices of entrepreneurial activities of other universities across the 
globe.

Business students are the future entrepreneurs and labor force of the society so it is a must to develop their personal entrepreneurial competency. According to [34] the success and failure of the business depends heavily on the person's competencies. Entrepreneurial competencies consist of components that are extremely rooted in a person's background (traits, personality, attitudes, social role and self-image) as well as those that can be obtained at work or in the course of training and education (skills, knowledge and experience) [35].

\section{Author's Profile}

Dr. Nerisa N. Paladan received her Doctor in Business Administration from Ateneo de Naga University, Naga City, Philippines. She is currently a Visiting Faculty at International University of Grand Bassam, Ivory Coast. She was a former Assistant Professor at Global Educational Center, Gyeongju University, South Korea for two years and a former Associate Professor at Ateneo de Naga University, Philippines for seven years. As a professor, she engaged herself in researches related to entrepreneurship, leadership, social responsibility and other related business topics. One of her professional advancements involves "international engagement" through active participation in international conferences as paper presenter, session chair, referee and program committee member. She also published research paper in peer reviewed journal in an international publication. She was chosen as the head of the Philippine delegation for the 2011-Phil-Korea Bilateral Youth Exchange Program. Furthermore, she also worked as accountant/bookkeeper and audit staff in various industries and corporation for almost five years prior to her involvement in the academe.

\section{REFERENCES}

[1] Scarborough, N. M. and T. W. Zimmerer (2003). Effective small business management: An entrepreneurial approach. Upper Saddle River, NJ, Prentice Hall.

[2] Kuratko, D. F. and R. M. Hodgetts (2004). Entrepreneurship: Theory, Process and Practice. Ohio, US, Thomson Learning.

[3] Venkatachalam, V. B. and A. A. Waqif (2005). "Outlook on integrating entrepreneurship in management education in India." Decision 32(2): 57-71.

[4] Audretsch, D.B, Keilback, M.C. \& Jagannadha, P.T. (2009) Introduction: Entrepreneurship and Innovation in Germany and India in Sustaining entrepreneurship and economic growth: lessons in policy and industry innovations from Germany and India. Edited by Zoria. New York; London: Springer.

[5] Lena, L. and P. K. Wong (2003). "Attitude towards entrepreneurship education and new venture creation."
Journal of Enterprising Culture 11(4): 339-357.

[6] Karanassios, N \& Pazarskis, M (2006). 'EU strategies to encourage youth entrepreneurship: Evidence from higher education in Greece.' Industry \& Higher Education, February: 43-50.

[7] Binks, M., Starkey, K. and Mahon, C.L. (2006) Entrepreneurship Education and The Business School. Technology Analysis \& Strategic Management, 18(1), 1-18.

[8] Alberti, F., S. Sciascia, S. \& Poli, A. (2004). Entrepreneurship education: Note on an ongoing debate. Proceeding of the 14th Annual Entrepreneurial Conference. University of Napoli Federico II, Italy: 4-7.

[9] Timmons, J.A. \& Spinelli S. (2009). New venture creation entrepreneurship for the 21st Century. 8th ed. Boston, MA: McGraw-Hill.

[10] Maas, G., \& Herrington, M. (2006). Global Entrepreneurship Monitor South Africa report. [Online] Available: http://www.gemconsortium.org/document.aspx?id756 (June 6, 2008).

[11] Inyang B.J., \& Enuoh, R.O (2009). Entrepreneurial Competencies: The Missing Links to Successful Entrepreneurship in Nigeria. International Business Research, 2(2): 62-71.

[12] Bagheri A., \& Pihie, Z.A.L. (2011). Student Entrepreneurial Leaders: Challenges and Competencies of Leading University Entrepreneurship Programs. International Journal of Business and Social Science, 2 (2):133-144.

[13] Mitchelmore, S., \& Rowley, J. (2013) Entrepreneurial competencies of women entrepreneurs pursuing business growth. Journal of Small Business and Enterprise Development, 20(1): 125 - 142.

[14] Dixon, R., Meier, R. L., Brown, D. C., \& Custer, R. L. (2005). The critical entrepreneurial competencies required by instructors from institution-based enterprises: A Jamaican study. Journal of Industrial Teacher Education, 42(4): 25-51.

[15] Colombo, M.G. and Grilli, L. (2005), "Founders' human capital and the growth of new technology- based firms: a competence-based view", Research Policy, Vol. 34 No. 6, pp. 795- 816 .

[16] Phelan, C., \& Sharpley, R. (2012). Exploring entrepreneurial skills and competencies in farm tourism. Local Economy 27(2): 103-118.

[17] Adegbite, S. A., Ilori, M. O.; Irefin, I. A.,' Abereijo, I. O.; \& Aderemi, H.O.S. Evaluation of the Impact of Entrepreneurial Characteristics on Performance of Small Scale Manufacturing Industries in Nigeria. Volume III, Issue 1, (c) 2006, Journal of Asia Entrepreneurship and Sustainability. Retrieved from

[18] Co, M. J., \& Mitchell, B. (2006). Entrepreneurship education in South Africa: A nationwide survey. Education \& Training Journal, 48(5), 348-359.

[19] Bygrave, W. D. Z., A., Ed. (2004). The portable MBA in entrepreneurship. The entrepreneurial process. New Jersey, John Wiley \& Sons, Inc.

[20] Heinonen, J., \& Poikkijoki, S. (2006). An entrepreneurial-directed approach to entrepreneurship education: Mission impossible? Journal of Management Development, 25(1), 80-94. 
[21] Essia, Uwen (2012). Entrepreneurial Culturing of Formal Education Programmes in Nigeria, Journal of Sustainable Society, Vol. 1, No.2: 52-62.

[22] Bautista, R. S., Barlis, M. J. P., \& Nazario, A.G. (2007). The Personal Entrepreneurial Competencies of BS Entrepreneurship Students of the Cordillera Administrative Region and Practicing Entrepreneurs in the Cities of Baguio, Dagupan, and San Fernando, La Union: A Comparison. 10th National Convention on Statistics (NCS) EDSA Shangri-La Hotel October1-2,2007. Retrieved from http://www.nscb.gov.ph/ncs/10thNCS/papers/invited\%20pap ers/ips-06/ips06-02.pdf

[23] Rasheed, S. H. (2001). Developing Entrepreneurial Characteristics in Youth: The Effects of Education and Enterprise Experience. International Journal of Entrepreneurship Education. Retrieved from http://www.sbaer.uca.edu/research/usasbe/2001/pdffiles/pap ers/Volume2/063.pdf

[24] Sabarre, Antonia L. (2013). Dominant Personal Characteristics of Students in a Home Arts Entrepreneurship Course", Education and Development Conference 2013 Conference Proceedings, Bangkok, Thailand.

[25] World Economic Forum (2009) Educating the next wave of entrepreneurs: unlocking entrepreneurial capabilities to meet the global challenges of the 21st Century: A Report of the Global Education Initiative, Switzerland, Retrieved, March 8 , 2012 from https://members.weforum.org/pdf/GEI/2009/Entrepreneurshi p_Education_Report.pdf

[26] David B. Audretsch \& Mark Sanders, 2007. "Globalization and the Rise of the Entrepreneurial Economy," Jena Economic Research Papers 2007-003, FriedrichSchiller-University Jena, Max- Planck-Institute of
Economics

[27] Azarcon, Ernie Roy S. (2008). Entrepreneurship principles and practices, Philippines: Valencia Educational Supply, Baguio City.

[28] Patton M 2002, Qualitative Research and Evaluation Methods, Sage Publications, Thousand Oaks, California.

[29] Beeka, B.H., \& Rimmington, M. (2011).Entrepreneurship as a career option for African youths. Journal of Development Entrepreneurship, 16(1): 145-164.

[30] Buang, N.A. (2011). Managing Quality Entrepreneurship Course for Community College Students in Malaysia. International Business Management, 5(5): 255-265.

[31] Sardeshmukh, S.R., \& Smith-Nelson, R. (2011). Educating for an entrepreneurial career: developing opportunity recognition ability. Australian Journal of Career Development, 20(3): 47-55.

[32] Calvin, R. J. (2003). Entrepreneurial management. New York: The McGraw Hill Executive MBA Series. International Edition.

[33] Davis, C. (2010). Entrepreneurial Characteristics: Your Key to Success. Retrieved from http://entrepreneur.ezinemark.com/entrepreneurial-characteri stics-your-key-tosuccess- 318a28b8ee8.html

[34] Capaldo, G., Iandoli, L. and Ponsiglione, C. (2004), "Entrepreneurial competencies and training needs of small firms", paper presented at 14th Annual IntEnt Conference, Napoli.

[35] Man, T.W.Y. and Lau, T. (2005), "The context of entrepreneurship in Hong Kong”, Journal of Small Business and Enterprise Development, Vol. 12 No. 4, pp. 464-81. 